\title{
Plant-Soil Relationships on Bentonite Mine Spoils and Sagebrush-grassland in the Northern High Plains
}

\author{
CAROLYN HULL SIEG, DANIEL W. URESK, AND RICHARD M. HANSEN
}

\section{Abstract}

Plant canopy cover, standing crop, and soils were sampled on (1) old (unreclaimed), (2) reclaimed, (3) semireclaimed (newly mined) bentonite mine spoils and (4) native sagebrush-grass rangelands in southeastern Montana. Plant cover and standing crop were higher on sagebrush-grass rangelands than on all bentonite spoils. Scurfless saltbush (Atriplex suckleyi) was the most successful and abundant plant on bentonite spoils. Soil chemical analyses indicated that low pH, excessive salinity and sodium, plus soil compaction were limiting for plant growth and establishment on bentonite spoils.

Biological renovation of bentonite clay mine spoils in the northern Great Plains represents an important and challenging problem for reclamation specialists. The bulk of the world's supply of mineable sodium bentonite is in the region (Knechtel and Patterson 1962), and surface mining for bentonite will likely disturb a larger land area than is disturbed by coal mining, at least in the state of Montana (National Academy of Science/National Academy of Engineering 1973). Further, bentonite spoils are difficult to revegetate. Physical and chemical properties of the spoils materials, sparse and low quality topsoil, low annual precipitation, and livestock grazing present problems in reclamation of these lands (Hemmer et al. 1977).

Published information is rare on revegetation techniques, natural plant growth, and soil properties of bentonite spoils. Hemmer et al. (1977) attempted to enhance plant establishment on bentonite spoils by using various methods of seeding and seed bed preparation. Bjugstad (1979) and Bjugstad et al. (1981) reported on shrub plantings in bentonite spoil material. The purpose of the current investigation was to provide baseline information on plant communities and soils associated with bentonite mine spoils and native sagebrush-grass rangelands in an effort to (1) evaluate the success of reclamation efforts; (2) identify plant species adapted to bentonite spoil environments; and (3) identify soil (or spoil) properties which limit plant growth.

\section{Study Area and Methods}

This study was conducted in Carter County, Mont., approximately $9 \mathrm{~km}$ west of Alzada (Fig. 1). The study area was on a dense clay-clayey-saline upland range site complex (Ross and Hunter 1976), in a sagebrush-saltbush/southeastern grassland vegetation type (Payne 1973). Elevations ranged from 1000 to $1100 \mathrm{~m}$. Major shrubs were big sagebrush (Artemisia tridentata) and plains

Sieg is wildlife biologist, and Uresk is research biologist, Rocky Mountain Forest and Range Experiment Station. Rapid City, S. Dak.. in cooperation with the South Dakota School of Mines and Technology. The Station's headquarters is in Fort Collins, in cooperation with Colorado State University. Hansen is professor, Range Science Department, Colorado State University, Fort Collins.

Appreciation is extended to Lynn Alexander, Colorado State University, for help with field work. The authors thank the owners of the Wyotana Ranch for their cooperation in this study and NL Industries, Baroid Division and International Minerals \& Chemical Corporation for permission to use their land.

Manuscript received April 19;, 1982.

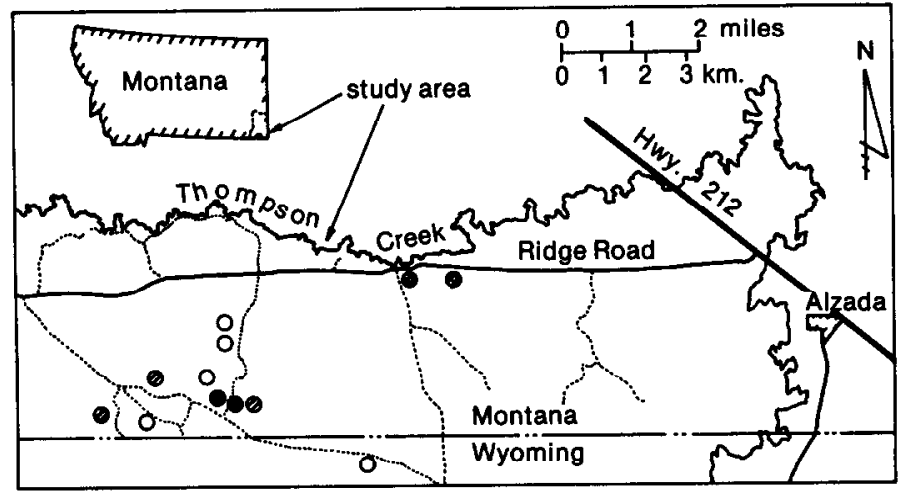

Study sites:

$O=$ Old spoils

0 = Reclaimed spoils

- Semireclaimed spoils

Fig. 1. Map of the study area, with regional orientation, showing the locations of the 12 study sites near Alzada, Mont.

prickly pear (Opuntia polyacantha). Prevalent grasses included western wheatgrass (Agropyron smithii), buffalograss (Buchloe dactyloides), and blue grama (Bouteloua gracilis). Scarlet globemallow (Sphaeralcea coccinea) was the most common forb. Unreclaimed mine spoils were dominated by scurfless saltbush (Atriplex suckleyi). The characteristically scanty vegetation of reclaimed spoils was generally composed of scurfless saltbush, crested wheatgrass (Agropyron cristatum), and western wheatgrass.

The area receives an annual average of $37 \mathrm{~cm}$ of precipitation, of which nearly $50 \%(18 \mathrm{~cm})$ is accumulated between May and July (National Oceanic and Atmospheric Administration 1976). In 1979 and 1980,26 and $35 \mathrm{~cm}$ of precipitation were received, respectively. The growing season (May to July) total for 1979 was $15 \mathrm{~cm}$, while only $11 \mathrm{~cm}$ was received during this period in 1980 . Snowfalls are frequent from November through April, accumulating an annual average of $95 \mathrm{~cm}$. The mean temperature is $7.8^{\circ} \mathrm{C}$, ranging from $-6.4^{\circ} \mathrm{C}$ in January to $22.6^{\circ} \mathrm{C}$ in July.

Bentonite, a sodic montmorillonitic type clay, has been mined from the Belle Fourche and Mowry shale formations in this area for over 60 years (Knechtel and Patterson 1962). Bentonite is primarily used in oil well drilling mud and as a reservoir sea lant, but is also used to clarify wine; as a binder in cosmetics, chocolate, and aspirin; and is important in the production of a remarkable variety of products (Hemmer et al. 1977). The clay is mined with scrapers and crawler tractors (Fig. 2), resulting in pits less than 5 ha in size and rarely deeper than $15 \mathrm{~m}$. Mining companies often have several pits open at one time to meet market demands for various grades of the clay.

Before reclamation laws were passed in the late 1960 's, the overburden and cleanings (a mixture of bentonite and overburden) were left in steep piles, without any attempt to revegetate them. Thus, old mine spoil heaps are essentially devoid of vegetation and severely eroded (Fig. 2). Spoil piles made after 1968 have been 


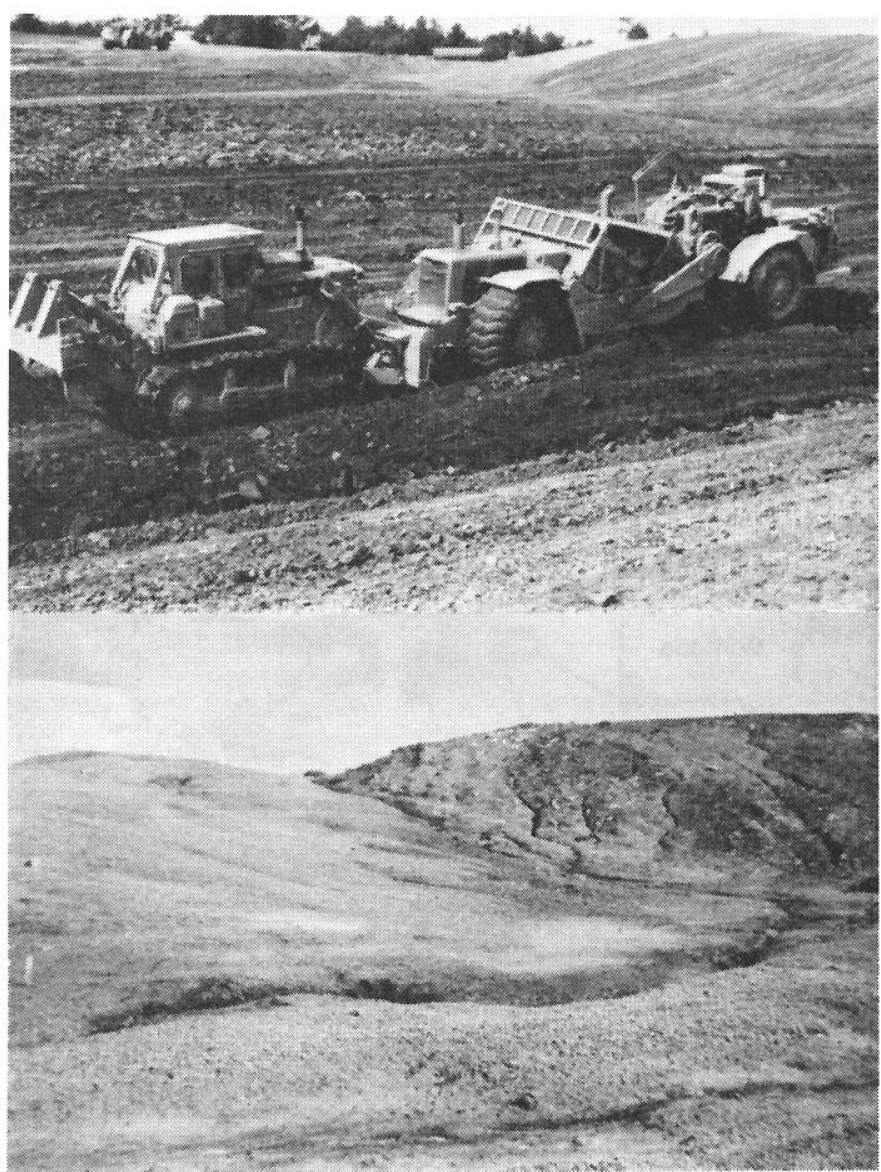

Fig. 2. Bentonite is mined with crawler tractors and scrapers, resulting in pits less than 5 ha in size (top). Old spoils, like this one mined in 1954, are steep, barren, and eroded (bottom).

contoured, covered with a thin layer of topsoil and seeded. Because of the patchiness of both the mining and the attempted revegetation, a broad spectrum of spoil types is present, which afforded the opportunity to examine plant-soil relationships on recently mined spoils, older spoils, and in native vegetation.

Twelve $60 \times 60 \mathrm{~m}(0.36 \mathrm{ha})$ study sites were selected: 10 on bentonite mine spoils established between 1952 and 1978 and 2 in the adjacent unmined vegetation (Fig. 1).

The study sites were classified into four types: (1) old mine spoils; (2) reclaimed spoils; (3) semireclaimed spoils; and (4) sagebrushgrass rangeland. Five study sites were established on old mine spoils (12 to 28 years old predating reclamation laws) which were steep and sparsely vegetated. Three sites were established on reclaimed mine spoils ( 5 to 12 years old) which had been contoured, spread with topsoil and seeded with a mixture of wheatgrasses (Agropyron spp.) and yellow sweetclover (Melilotus officinalis). Two sites were established on (recently mined) semireclaimed bentonite mine spoils. Both of these semireclaimed spoil sites were constructed, contoured, and spread with topsoil in 1978. Of these 2 sites, one spoil area was seeded in 1979, while the steep grade of the other spoil prevented seeding. Two additional study sites were established in gently undulating unmined big sagebrushgrass rangeland. All sites were grazed by sheep and cattle.

Plant canopy cover was estimated on the 12 sites during late spring, mid-summer and late summer of 1979 and 1980. Plant canopy cover was estimated in 150 quadrats $(20 \times 50 \mathrm{~cm})$ placed at 1 -m intervals along 3 permanent $50-\mathrm{m}$ line transects on each site using methods modified from Daubenmire (1959). Canopy cover was visually estimated by the use of 7 cover classes: $0=$ less than $1 \%$ cover; $1=1$ to $5 \% ; 2=5$ to $25 \% ; 3=25$ to $50 \% ; 4=50$ to $75 \% ; 5=$ 75 to $95 \%$; and $6=95$ to $100 \%$ cover. Plants were identified using Nickerson et al. (1976).
Plant standing crop was estimated by harvesting all plants except big sagebrush at ground level annually at estimated peak production (late July) on all sites. Harvesting was conducted in ten $20 \times 50 \mathrm{~cm}$ quadrats on each of 3 permanent transects. Plant species were separated in the field, oven dried in the laboratory at $60^{\circ} \mathrm{C}$ for 48 hours, and weighed.

Twenty soil samples were taken on each site. A grid pattern with 15-m spacing was used to distribute the samples throughout the sites. The samples were taken to a depth of $10-\mathrm{cm}$ with a $5-\mathrm{cm}$ soil probe mounted on a drill truck. Four composite subsamples were prepared for analysis from the 20 samples on each site: 2 were obtained by mixing and halving the first 10 samples, and 2 more were obtained in a similar manner from the next ten samples. Soil analyses conducted by the U.S. Testing Company in Richland, Wash., included $\mathrm{pH}$, electrical conductivity, and available levels of potassium, calcium, magnesium, nitrate nitrogen, sodium, sulphur, and boron.

Soil compaction was measured with a hand-held penetrometer scaled from 0 to $4.5 \mathrm{~kg} / \mathrm{cm}^{2}$. The load required to read $4.5 \mathrm{~kg} / \mathrm{cm}^{2}$ was $7.7 \mathrm{~kg}$. Twelve measurements were taken on each site every 3 weeks from May to October 1980.

One and two-way (incorporating both years) analysis of variance and Tukey's multiple comparison procedure (Kleinbaum and Kupper 1978) were used to compare plant canopy cover, average aboveground biomass, and the soil physical and chemical properties among site types. Chi square contingency tables and Spearman's rank order correlation coefficient (Steel and Torrie 1980) were used to compare plant composition between years.

\section{Results}

\section{Canopy Cover}

Total plant canopy cover was higher $(P<0.05)$ on sagebrushgrass rangelands (averaging $32 \%$ ), when compared to all bentonite mine spoils (Table 1). The shrub species with the highest percentage cover on the sagebrush-grasslands included big sagebrush (19\%), broom snakeweed (Gutierrezia sarothrae) $(<1 \%)$, and plains prickly pear $(<1 \%)$. Grass cover was approximately $14 \%$ of the total cover, and was dominated by western wheatgrass, green needlegrass (Stipa viridula), and buffalograss. Twenty-eight forb species contributed only slightly to the total plant cover. The forb species contributing most to the plant cover were Hood's phlox (Phlox hoodii) and selaginella (Selaginella densa). Lichen (Parmelia chlorochrae) cover averaged $3 \%$.

Canopy cover on reclaimed mine spoils (12\%) was greater $(P<0.05)$ than cover on old and semireclaimed mine spoils (Table 1). The most prominent plant species on reclaimed bentonite spoils was scurfless saltbush (Fig. 3), followed by western wheatgrass and crested wheatgrass. Forty-two plant species were present on the 11and 12-year-old reclaimed spoils, while plant cover was limited to 19 species on reclaimed mine spoils 5 and 6 years old. Buffalograss and tumblegrass (Schedonnardus paniculatus) were important plants on the 11- and 12-year-old spoils.

Plant canopy cover averaged $3 \%$ on both semireclaimed bentonite mine spoils and on old spoils (Table 1). Scurfless saltbush provided the most cover of 19 species found on semireclaimed spoils, followed by Russian thistle (Salsola kali) and wheatgrasses. Scurfless saltbush provided over $50 \%$ of the canopy cover on old spoils (Table 1). Other common plant species contributing less than $1 \%$ each were curlycup gumweed (Grindelia squarrosa), bushy knotweed (Polygonum ramosissimum), foxtail barley (Hordeum jubatum), and big sagebrush.

Plant canopy cover decreased from 1979 to 1980 on 2 of the 4 site types. Canopy cover on the sagebrush-grass rangelands and reclaimed mine spoils was lower $(P<0.05)$ in 1980 than in 1979 . Canopy cover was not different between the 2 years on the old mine spoils. The semireclaimed spoils were the only sites to show an increase $(P<0.01)$ in canopy cover in 1980 (see Fig. 4 for general trends). The rank order of plant species on the 4 site types was significantly $(P<0.05)$ correlated for the 2 years, indicating that 
Table 1. Two-year average percent plant canopy cover, litter, bareground, and percent cover of major plant species on bentonite mine spoils and sagebrush rangeland, near Alzada, Mont.

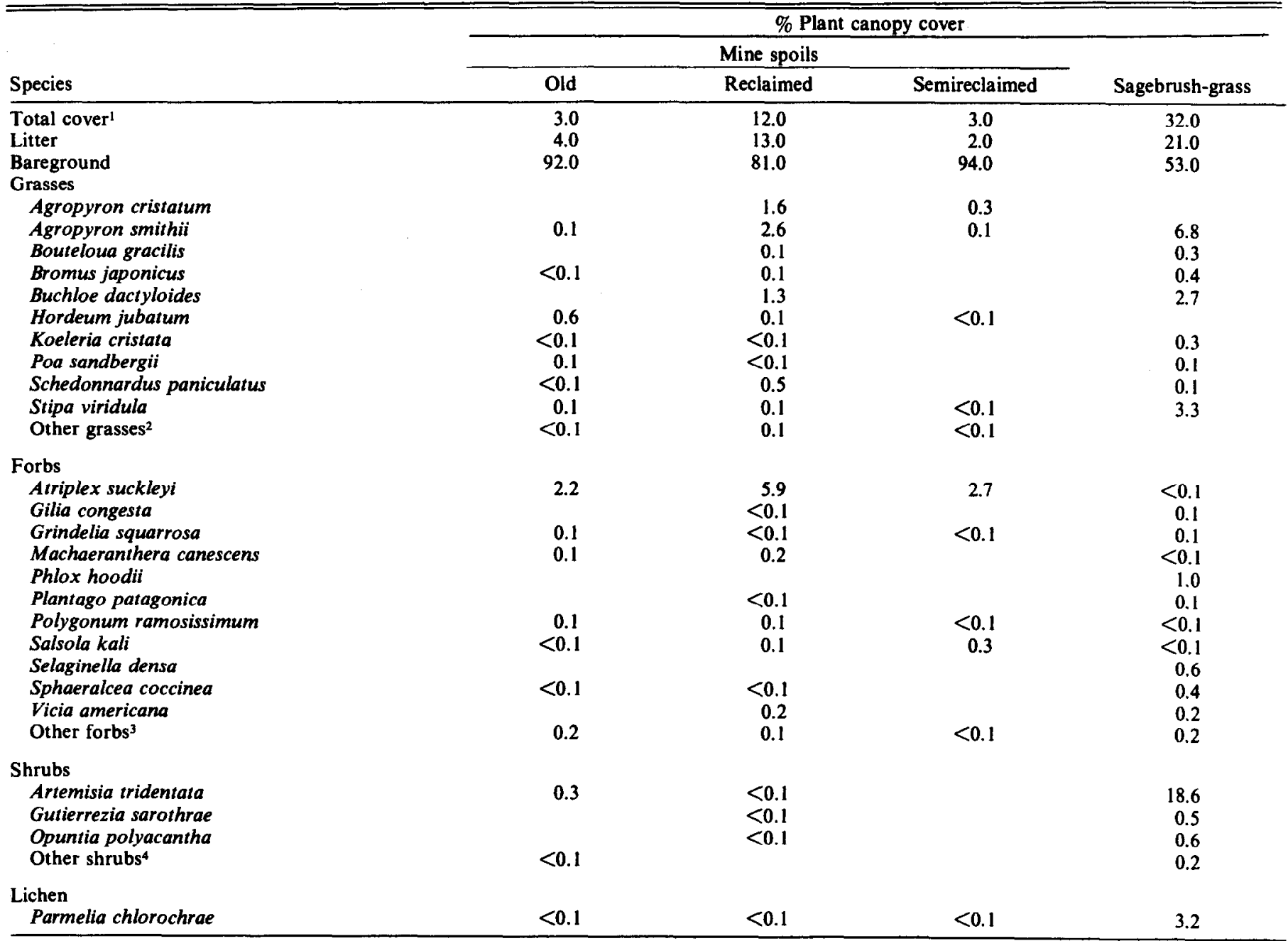

1Two dimensional cover.

${ }^{2}$ Agropyron dasytachyum, Bromus inermis, Bromus tectorum, Sporobolus spp.

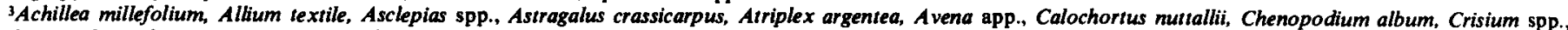

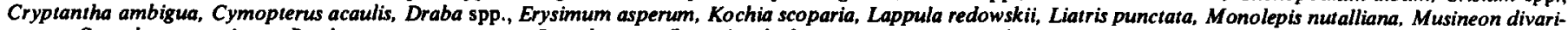
catum, Oenothera caespitosa, Petalostemon purpureum, Psoralea tenuiflora, Sueda fruticsoa, Taraxacum oficinale, Tragopogon dubius, unknown forbs.

"Atriplex gardneri, Chrysothamnus nouseosus, Sarcobatus vermiculatus.

plant species composition on each site type did not change between years.

\section{Standing Crop}

Average standing crop for the 2 years combined was higher $(P<0.05)$ on sagebrush-grass rangelands than on the mine spoils (Fig. 4). Harvested plant material on sagebrush-grass rangelands averaged $428 \mathrm{~kg} / \mathrm{ha} / \mathrm{yr}$. Plant species with the greatest standing crop in decreasing order, were western wheatgrass, lichen, green needlegrass, and buffalograss (Table 2). Total forb production averaged $53 \mathrm{~kg} / \mathrm{ha}$ and included 15 species. Major forbs were Hood's phlox, scarlet globemallow, and curlycup gumweed.

Standing crop was higher $(P<0.05)$ on reclaimed mine spoils than on old spoils and semireclaimed mine spoils, although in 1980 , the biomass for reclaimed spoils was not greater than other spoils (Fig. 4). Harvested plant material on reclaimed mine spoils averaged $231 \mathrm{~kg} / \mathrm{ha} / \mathrm{yr}$ (Table 2). Scurfless saltbush provided most of the harvested plant material, followed by western wheatgrass and crested wheatgrass. Buffalograss, tumblegrass, common yarrow (Achillea millefolium), hoary aster (Machaeranthera canescens), dandelion (Taraxacum officinale), and American vetch (Vicia americana) were abundant species on the 11- and 12-yearold relcaimed mine spoils.

Average standing crop per year was not significantly different
$(P>0.05)$ on semireclaimed mine spoils $(91 \mathrm{~kg} / \mathrm{ha})$ and old spoils (56 kg/ha) (Fig. 4). Scurfless saltbush biomass on semireclaimed spoils averaged $76 \mathrm{~kg}$ / ha for both yers, followed by Russian thistle, western wheatgrass, and Nuttall's monolepis (Monolepis nuttalliana) (Table 2).

Nearly $50 \%$ of the harvested plant material on the old mine spoils consisted of scurfless saltbush (Table 2). Wheatgrasses, foxtail barley, and bushy knotweed were less important contributors to the total standing crop. Five plant species including eriogonum (Eriogonum sp.), common yarrow, and curlycup gumweed were found only on 1 old mine spoil site.

Yearly differences in standing crop on the various sites were similar to trends reported for plant canopy cover. Standing crop was lower $(P<0.03)$ in 1980 on sagebrush-grass rangelands and reclaimed mine spoils than in 1979 , while production increased $(P<0.01)$ from 1979 to 1980 on the semireclaimed spoils (Fig. 4). Aboveground biomass on old mine spoils did not differ significantly from 1979 to 1980 .

\section{Soils}

The results of the soil chemical analysis are presented in Table 3. Available levels of calcium and magnesium were similar on bentonite mine spoils and sagebrush-grass rangelands. However, $\mathrm{pH}$, other nutrient concentrations, electrical conductivity $\left(E_{e}\right)$, and 


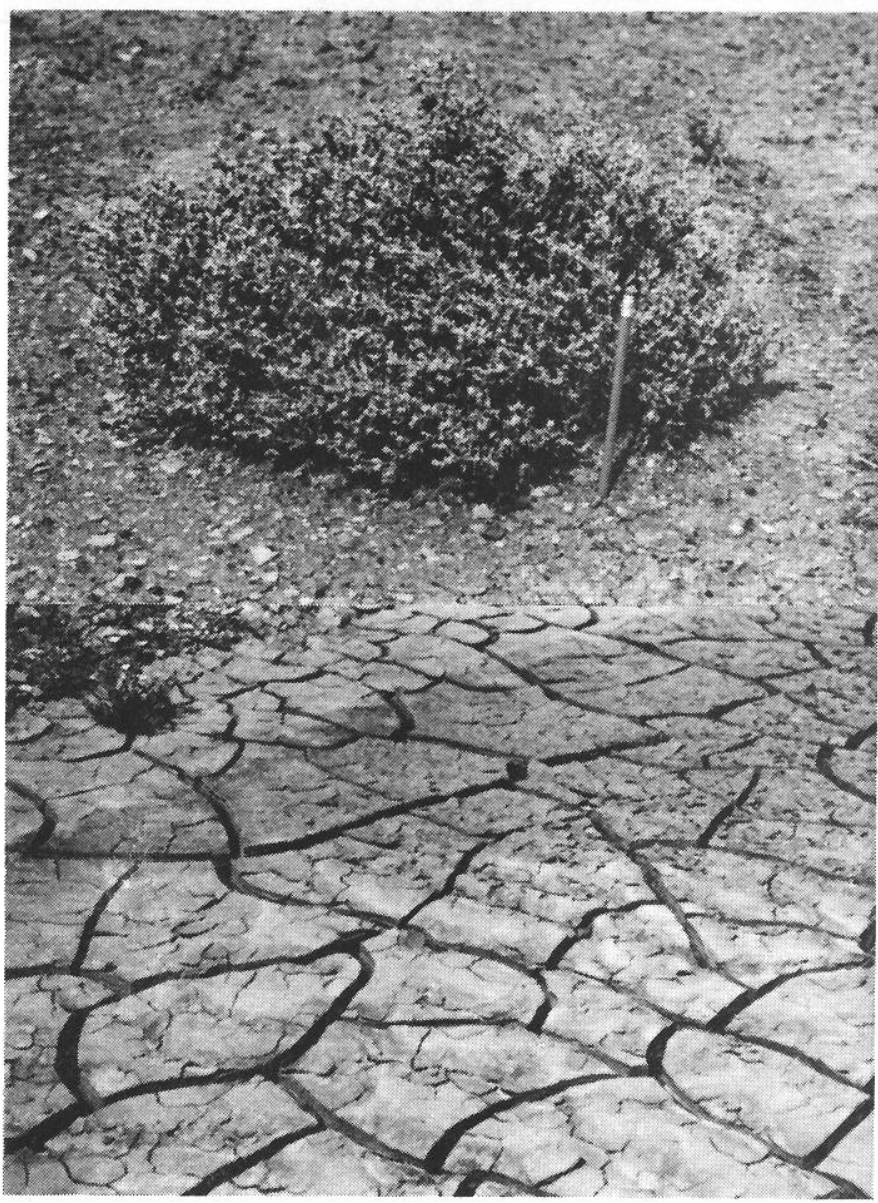

Fig. 3. Scurfless saltbush (Atriplex suckleyi) was the most common plant on the bentonite mine spoils (top). The high sodium content in the spoils material causes surface cracking when dry (bottom).

soil compaction (Table 4) were significantly different between bentonite spoils and sagebrush-grass rangelands.

Average $\mathrm{pH}$ varied from 5.6 on old bentonite mine spoils to 7.1 on sagebrush-grass rangelands (Fig. 5). Average $\mathrm{pH}$ on old spoils were lower $(P<0.05)$ than on all other sites, while the $\mathrm{pH}$ on

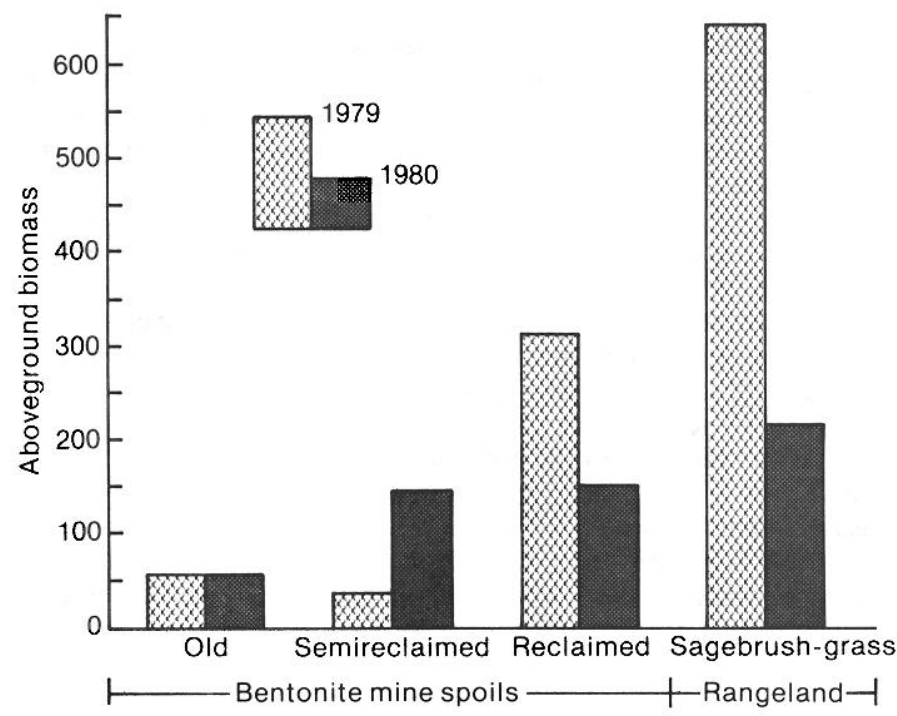

Fig. 4. Average aboveground biomass $(\mathrm{kg} / \mathrm{ha})$ on bentonite mine spoils and sagebrush-grass rangelands in 1979 and 1980, near Alzada, Mont. Plant canopy cover demonstrated similar trends.

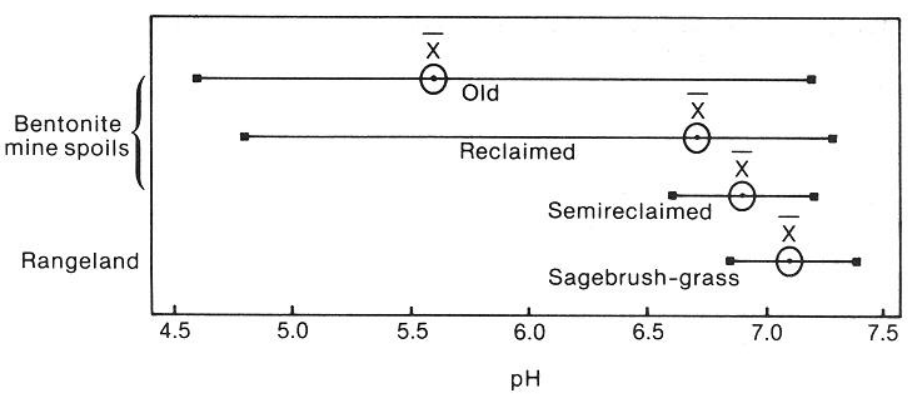

Fig. 5. The range and average of the $p H$ from soil samples taken on bentonite mine spoils and sagebrush-grass rangelands in 1980, near Alzada, Mont.

reclaimed spoils, semireclaimed spoils, and sagebrush-grasslands were similar. $\mathrm{pH}$ values were highly variable on old spoils and reclaimed spoils, ranging from strongly acid to neutral, while values on semireclaimed spoils and sagebrush-grass rangelands were all between 6.5 and 7.4 .

Potassium, nitrate nitrogen, and total sodium concentrations did not differ between old and semireclaimed mine spoils and were higher on these sites than on reclaimed bentonite spoils and sagebrush-grasslands (Table 3). Values were similar on reclaimed spoils and sagebrush-grasslands. $\mathrm{EC}_{\mathrm{e}}$ generally demonstrated similar trends, although the average $\mathrm{EC}_{\mathrm{e}}$ value on sagebrush-grass rangelands was nonsaline $(1.5 \mathrm{mmhos} / \mathrm{cm})$ and values on the bentonite mine spoils were all in the saline range (from 5.5 to 9.3 $\mathrm{mmhos} / \mathrm{cm}$ ) (Fig. 6). $\mathrm{EC}_{\mathrm{e}}$ on old bentonite mine spoils displayed the greatest variability.

Sulphur and boron concentrations averaged from 1,159 to 2,753 ppm and from 1.7 to $3.3 \mathrm{ppm}$, respectively (Table 3 ). Soil sulphur concentrations were similar on the bentonite mine spoils and higher $(P<0.05)$ than concentrations on the sagebrush-grass rangelands. Boron concentrations did not differ on semireclaimed spoils, reclaimed spoils, and sagebrush-grasslands and were higher $(P<0.05)$ on these sites than on the old bentonite mine spoils.

Average soil compaction values ranged from $1.7 \mathrm{~kg} / \mathrm{cm}^{2}$ on the sagebrush-grass rangelands to $3.6 \mathrm{~kg} / \mathrm{cm}^{2}$ on old bentonite mine spoils (Table 4). Average soil compaction was similar on the mine spoil sites and significantly higher $(P<0.05)$ than on the sagebrushgrasslands.

\section{Discussion}

This study provided evidence that biological renovation of bentonite mine spoils is a challenging problem, but without some attempt to relcaim spoil piles, plant growth will be severely limited by the chemical and physical properties of the spoils materials. In spite of the yearly variations in plant canopy cover and standing crop, which were attributed to precipitation fluctuations and livestock grazing, reclamation efforts (conturing, spreading topsoil, and seeding) on the sites in this study provided slightly encouraging results. The addition of topsoil to the spoil piles did not always

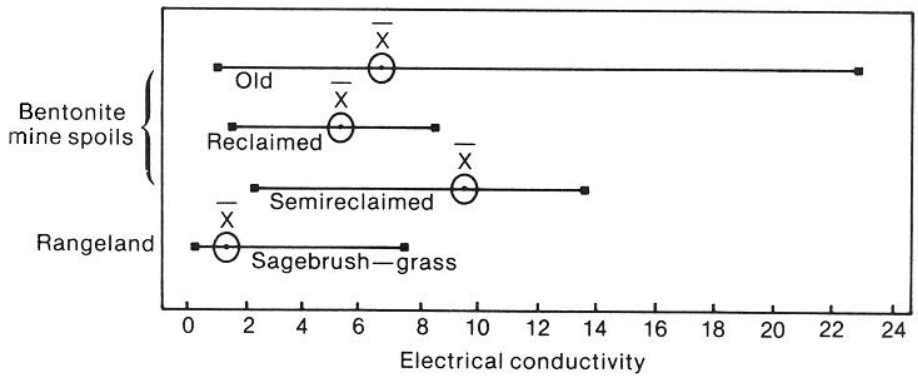

Fig. 6. The range of electrical conductivity values $(\mathrm{mmhos} / \mathrm{cm})$ and average values from soil samples taken on bentonite mine spoils and sagebrush-grass rangelands in 1980, near Alzada, Mont. 
Table 2. Two-year mean eatimated standing crop (kg/ha) of major plant species on bentonite mine spoils and adjacent sagebrush-grass rangelands, near Alzada, Mont. (bis sagebrush excluded).

\begin{tabular}{|c|c|c|c|c|}
\hline \multirow[b]{3}{*}{ Species } & \multicolumn{4}{|c|}{ Plant standing crop (kg/ha) } \\
\hline & \multicolumn{3}{|c|}{ Mine spoils } & \multirow[b]{2}{*}{ Sagebrush-grass } \\
\hline & Old & Reclaimed & Semireclaimed & \\
\hline \multicolumn{5}{|l|}{ Grasses } \\
\hline Agropyron spp. & 12.0 & & & \\
\hline Agropyron cristatum & $<1$ & 17 & & \\
\hline Agropyron smithii & & 27 & 4 & 166 \\
\hline Bouteloua gracilis & & & & 4 \\
\hline Bromus japonicus & 1 & 7 & & 11 \\
\hline Bromus tectorum & & I & & \\
\hline Buchloe dactyloides & & 16 & & 24 \\
\hline Hordeum jubatum & 6 & 3 & & \\
\hline Koeleria cristata & & & & 8 \\
\hline Poa sandbergii & 1 & 1 & & 4 \\
\hline Schedonnardus paniculatus & & 11 & & 2 \\
\hline Sporobolus sp. & & 1 & & \\
\hline Stipa viridula & $<1$ & $i$ & & 60 \\
\hline \multicolumn{5}{|l|}{ Forbs } \\
\hline Achillea millefolium & 2 & 3 & & \\
\hline Allium textile & & & & 2 \\
\hline Astragalus spp. & & & & $<1$ \\
\hline Atriplex suckleyi & 27 & 116 & 76 & 1 \\
\hline Cirsium spp. & 27 & & 0 & 4 \\
\hline Eriogonum sp. & 2 & & & \\
\hline Gilia congesta & & 1 & & 1 \\
\hline Grindelia squarrosa & 1 & i & & 7 \\
\hline Machaeranthera canescens & 1 & 2 & & 1 \\
\hline Monolepis nuttalliana & & & 3 & 1 \\
\hline Musineon divaricatum & & & & 1 \\
\hline Phlox hoodii & & & & 16 \\
\hline Plantago patagonica & & 1 & & $\begin{array}{r}10 \\
3\end{array}$ \\
\hline Polygonum ramosissimum & 3 & 5 & & $<1$ \\
\hline Salsola kali & & 9 & 9 & \\
\hline Sphaeralcea coccinea & & 1 & & 10 \\
\hline Taraxacum officinale & & 2 & & 1 \\
\hline Vicia americana & & 2 & & 3 \\
\hline Unknown forb & & $<1$ & & 2 \\
\hline \multicolumn{5}{|l|}{ Shrubs } \\
\hline Atriplex gardneri & & & & 4 \\
\hline Gutierrezia sarothrae & $<1$ & $\mathbf{I}$ & & 3 \\
\hline Opuntia polyacantha & & & & 11 \\
\hline \multicolumn{5}{|l|}{ Lichen } \\
\hline Parmelia chlorochrae & $<1$ & $<1$ & & 80 \\
\hline Total & 56 & 231 & 91 & 428 \\
\hline
\end{tabular}

alleviate undesirable chemical characteristics, which reflected the low quantity of topsoil and inadequate coverage of the spoils materials. Of the plant species used in the seed mixture, western wheatgrass and crested wheatgrass survived to a limited degree, while yellow sweet clover failed to become established in most cases. The expansion of native plant species from adjacent unmined rangelands onto reclaimed mine spoils was a slow process, but the presence of buffalograss, green needlegrass, and a few big sagebrush seedlings was evidence that reclaimed spoil piles may someday be productive rangelands. However, based on the slow plant succession rates observed in this study, it is conceivable that over 75 years will be required for the restoration of these disturbed sites to productive sagebrush-grasslands.

Natural plant succession on the old spoils in this study was either absent or at best a slow process. Steep spoils mined nearly 30 years ago remained barren and severely eroded, with only a few rare

Table 3. Average soll chemical values on bentonite mine spoils sagebrush-grassiands near Alzada, Mont. (0-10 cm depth).

\begin{tabular}{|c|c|c|c|c|c|c|c|c|c|}
\hline \multirow[b]{2}{*}{ Habitat type } & \multirow[b]{2}{*}{ pH } & \multicolumn{4}{|c|}{ Available nutrients } & \multirow{2}{*}{$\begin{array}{c}\text { Soluable } \\
\text { and } \\
\text { exchangeable } \\
\mathrm{Na}\end{array}$} & \multirow{2}{*}{$\begin{array}{c}\text { Electrical } \\
\text { conductivity }\end{array}$} & \multicolumn{2}{|c|}{ Micro-nutrients } \\
\hline & & $\mathbf{K}$ & $\mathrm{Ca}$ & $\mathbf{M g}$ & $N O_{3}-N$ & & & $\mathbf{S}$ & B \\
\hline & & ppm & \multicolumn{2}{|c|}{-meq/100gm- } & ppm & $\mathrm{meq} / 100 \mathrm{gm}$ & mmhos $/ \mathrm{cm}$ & & \\
\hline $\begin{array}{l}\text { Old mine spoils } \\
\text { Reclaimed spoils } \\
\text { Semireclaimed spoils } \\
\text { Sagebrush-grasslands }\end{array}$ & $\begin{array}{l}5.6^{-1} \\
6.7^{b} \\
6.9^{b} \\
7.1^{b}\end{array}$ & $\begin{array}{l}409^{a} \\
340^{b} \\
414^{a} \\
300^{b}\end{array}$ & $\begin{array}{l}20^{2} \\
23^{a} \\
21^{a} \\
19^{a}\end{array}$ & $\begin{array}{l}8.4^{a} \\
8.1^{a} \\
7.3^{a} \\
8.9^{a}\end{array}$ & $\begin{array}{r}8.6^{\mathrm{a}} \\
3.5^{\mathrm{b}} \\
13.9^{\mathrm{a}} \\
2.7^{\mathrm{b}}\end{array}$ & $\begin{array}{r}24.6^{n} \\
12.0^{b} \\
21.3^{a} \\
3.4^{b}\end{array}$ & $\begin{array}{l}6.7^{a} \\
5.5^{\mathrm{ab}} \\
9.3^{\mathrm{a}} \\
1.5^{\mathrm{b}}\end{array}$ & $\begin{array}{l}2753^{a} \\
2371^{a} \\
2675^{a} \\
1159^{b}\end{array}$ & $\begin{array}{l}1.7^{\mathrm{a}} \\
3.1^{\mathrm{b}} \\
3.3^{\mathrm{b}} \\
3.1^{\mathrm{b}}\end{array}$ \\
\hline
\end{tabular}

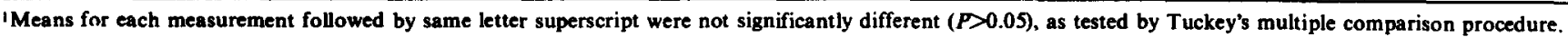


Table 4. A verage penetrometer readings $\left(\mathrm{kg} / \mathrm{cm}^{2}\right)$ on bentonite mine spoils and sagebrush-grass rangelands in 1980 near Alzada, Mont.

\begin{tabular}{|c|c|c|}
\hline Treatment & $N^{\prime}$ & $\overline{\bar{x}}^{2}$ \\
\hline Old spoils & 480 & $3.6^{\mathrm{a}} \pm 0.05$ \\
\hline Semireclaimed spoils & 288 & $3.0^{a} \pm 0.07$ \\
\hline Reclaimed spoils & 192 & $3.1^{\mathrm{a}} \pm 0.08$ \\
\hline Sagebrush-grass rangeland & 192 & $1.7^{\mathrm{b}} \pm 0.09$ \\
\hline
\end{tabular}

'Sample size, mean \pm standard error.

2Means followed by same letter superscript were not significantly different $(P>0.05)$, as determined by Tukey's multiple comparison procedure.

patches of vegetation. Scurfless saltbush, a native forb, demonstrated the highest degree of adaptability to the conditions on these spoils, although other plants were present in isolated microhabitats. Big sagebrush grew on a north-facing slope of one old spoil and sandberg bluegrass (Poa sandbergii) and green needlegrass wcrc associated with these clumps of big sagebrush. Foxtail barley occasionally grew in moist depressions. Litter accumulation, important in increasing the organic matter content in soils, was uncommon. It is likely that the biological productivity of these old spoils will change very little in this century.

The limited plant growth and production on the bentonite mine spoils in this study, when compared to sagebrush grasslands, was evidence of a harsh growing medium. The soils analyses indicated that the plant establishment problem was not based on nutritional deficiencies, but was the result of other physical and chemical properties of the spoils materials, such as low pH, soil salinity, high sodium and sulphur concentrations, and soil compaction.

Soil pH influences uptake of nutrients, with optimum uptake levels occurring between $\mathrm{pH} 6.5$ and 7.5 (United States Salinity Laboratory Staff 1954). Therefore, although available nutrients (potassium, calcium, magnesium, and nitrate) were present in adequate amounts for plant growth on the bentonite spoils in this study, uptake of these elements was impeded by acidic soils. This effect may have bee most pronounced on old spoils, where the $\mathrm{pH}$ was nearly consistently below pH 6.5. Acidic soils were less common on reclaimed and semireclaimed spoils and absent in native sagebrush grasslands, which is evidence that the addition of topsoil on mine spoils was helpful in alleviating acidic conditions.

Electrical conductivity above $4 \mathrm{mmhos} / \mathrm{cm}$ on the bentonite mine spoils was indicative of saline conditions requiring salt tolerant plant species and inhibiting water uptake by plants (United States Salinity Laboratory Staff 1954). High sodium concentrations on the bentonite spoils affected the physical structure of the spoils materials, causing soil particles to swell when wet and contributing to low aeration and impenetrable soil surfaces that crack when dry (Fig. 3). This expansion and cleavage of high sodium soils is detrimental to plant root structures and often results in low survival of plant seedlings.

Sulphur, a trace element in most soils, was present in large quantities, which conceivably contributed to a reduction in soil pH values through the formation of sulfic acid or oxidation of sulphide to acid (Bjugstad et al. 1981). Boron, required in very small quantities by plants, was present in toxic concentrations for some plants, both on the mine spoils and in the sagebrush-grass rangelands (United States Salinity Laboratory Staff 1954). The low boron levels on the old mine spoils were attributed to leaching from the steep slopes.
High penetrometer readings on the bentonite mine spoils indicated severe soil compaction. Values on the mine spoils were generally twice those of the sagebrush-grass rangelands, oftentimes measuring the maximum reading on the penetrometer. Compaction of the mine spoil material was attributed to the high sodic clay content of the spoils material (United States Geological Survey 1975), the effect of high sodium concentrations (United States Salinity Laboratory Staff 1954), to compaction from equipment during seed bed preparation (Hemmer et al. 1977), and to compaction from livestock trampling.

Hemmer et al. (1977), Bjugstad (1979), and Bjugstad et al. (1981) concurred on the difficulty of establishing plants on bentonite clay mine spoils. The results of this study indicate that natural plant succession on old bentonite spoils is a slow to non-existent process. Reclamation efforts encourage the growth of some plant species and lessen the adverse effects of the spoils materials. Research is needed to identify plants and methods to compensate for extremely varying soil $\mathrm{pH}$, high salinity, and compacted surfaces on bentonite clay spoils. Biologists would be prudent to take advantage of the pioneering abilities of scurfless saltbush in the efforts to renovate bentonite spoil environments in southeastern Montana.

\section{Literature Cited}

Bjugstad, A.J. 1979. Bentonite mine spoil and pit reclamation: A research problem. Proc. Mineral Waste Stabilization Committee, June 21, 1979, Eveleth, Minn. p. 1-19.

Bjugstad, A.J., T. Yamamoto, and D.W. Uresk. 1981. Shrub establishment on coal and bentonite clay mine spoils. Proc. Shrub Establishment on Disturbed Arid and Semi-Arid Lands Symp., Dec. 2-3, 1980, Laramie Wyo. p. 104-122.

Daubenmire, R. 1959. A canopy-coverage method of vegetation analysis. Northwest Sci. 33:43-64.

Hemmer, D., S. Johnson, and R. Beck. 1977. Bentonite mining relating reclamation problems in the northwestern states. Old West Regional Comm., Billings, Mont.

Kleinbaum, D.G., and L.L. Kupper. 1978. Applied regression analysis and other multivariable methods. Duxburg. Press. North Scituate, Mass.

Knechtel, M.M. and S.H. Patterson. 1962. Bentonite deposits of the Northern Black Hills District-Wyoming, Montana and South Dakota. Geological Survey Bulletin 1082-H. U.S. Gov. Printing Office. Washington, D.C. $1030 \mathrm{p}$.

National Academy of Science/National Academy of Engineering Study Committee on the Potential for Rehabilitating Lands Surface Mined for Coal in the Western United States. 1973. Rep. to the Energy Policy Proj. of the Ford Found., Washington, D.C.

National Oceanic and Atmospheric Administration. 1976. Climate of Colony, Wyoming. Climatography of the United States No. 20. Asheville, N.C.

Nickerson, M.F., G.E. Brink, and C. Feddema. 1976. Principal plants of the central and southern Rocky Mountains. Names and symbols. U.S. Dep. Agr. Forest Serv. General Tech. Rep. RM-20. Rocky Mountain Forest and Range Exp. Sta., Fort Collins, Colo.

Payne, G.F. 1973. Vegetative rangeland types in Montana. Bull. 671. Montana Agr. Exp. Sta., Bozeman.

Ross, R.L., and H.E. Hunter. 1976. Climax vegetation of Montana. U.S. Dep. Agr. Soil Conserv. Serv. Bozeman, Mont.

Steel, R.G., and J.H. Torrie. 1980. Principles and procedures of statistics. 2nd Ed. McGraw-Hill Book Co., Inc. New York, N.Y.

United States Geological Survey. 1975. Mineral and water resources of South Dakota. U.S. Gov. Print. Off., Washington, D.C.

United States Salinity Laboratory Staff. 1954. Diagnosis and improvement of saline and alkali soils. U.S. Dep. Agr. Handb. No. 60. Washington, D.C 